\title{
White paper: Enhancing adolescent financial capabilities through financial education in Bangladesh
}

\author{
Sajeda Amin \\ Population Council \\ Laila Rahman \\ Population Council \\ Sigma Ainul \\ Population Council \\ Ubaidur Rob \\ Population Council \\ Bushra Zaman \\ Population Council
}

See next page for additional authors

Follow this and additional works at: https://knowledgecommons.popcouncil.org/departments_sbsr-pgy

Part of the Gender Equity in Education Commons, International Public Health Commons, and the Social and Behavioral Sciences Commons

How does access to this work benefit you? Let us know!

\section{Recommended Citation}

Amin, Sajeda, Laila Rahman, Sigma Ainul, Ubaidur Rob, Bushra Zaman, and Rinat Akter. 2010. "White paper: Enhancing adolescent financial capabilities through financial education in Bangladesh." Dhaka: Population Council. 


\section{Authors}

Sajeda Amin, Laila Rahman, Sigma Ainul, Ubaidur Rob, Bushra Zaman, and Rinat Akter 


\section{WHITE PAPER}

Enhancing Adolescent Financial Capabilities through

Financial Education in Bangladesh

Sajeda Amin, Laila Rahman, Sigma Ainul, Ubaidur Rob

Bushra Zaman and Rinat Akter

\section{Population Council}

2010

(1) Population Council 


\section{WHITE PAPER}

Enhancing Adolescent Financial Capabilities through

Financial Education in Bangladesh

Sajeda Amin, Laila Rahman, Sigma Ainul, Ubaidur Rob

Bushra Zaman and Rinat Akter

Population Council

2010

Population Council

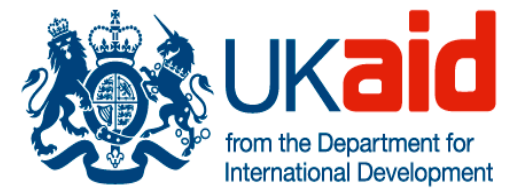




\title{
WHITE PAPER
}

\author{
Enhancing Adolescent Financial Capabilities through \\ Financial Education in Bangladesh
}

This publication has been made possible through the financial support of Department for International Development (DfID) in Bangladesh Grant No. PO40021306 in support of Promoting Financial Education through Mentoring Relationships for the period of September 1, 2009-September 30, 2010. The opinions expressed herein are those of the authors and do not reflect the views of the Population Council and DfID, Bangladesh.

Copyright (C) Population Council, 2010

\section{Suggested Citation}

Amin, Sajeda, Laila Rahman, Sigma Ainul, Ubaidur Rob, Bushra Zaman and Rinat Akter. 2010. "White Paper: Enhancing Adolescent Financial Capabilities through Financial Education in Bangladesh." Dhaka, Bangladesh: Population Council.

\section{Communication}

Population Council

House CES (B) 21, Road No. 118, Gulshan

Dhaka-1212, Bangladesh

Tel: $+880-2-8821227,8826657$

Fax: +880-2-8823127

Email: info.bangladesh@popcouncil.org; samin@popcouncil.org 


\section{CONTENTS}

Acknowledgements

Acronyms

vii

Partners- At a glance

viii

Executive summary

$i x$

Introduction 1

Objectives 1

Rationale 2

Scoping study on financial capabilities in Bangladesh 4

Evidence from the secondary data 5

Listening to girls' voices $\quad 6$

Consultative discussions with stakeholders 9

$\begin{array}{ll}\text { Review of financial literacy curriculums and programs } & 10\end{array}$

$\begin{array}{ll}\text { Financial education for the poor } & 10\end{array}$

Financial education versus entrepreneurship development 12

Teaching methods 13

Mentoring - An alternate pedagogy 14

Developing a financial education curriculum for girls 15

Defining mentoring in financial education 19

Theory of change for financial education impacting on the adolescent lives $\quad 20$

Pilot-testing a personal financial education curriculum 23

$\begin{array}{ll}\text { Challenges ahead } & 28\end{array}$

References $\quad 32$

Appendixes 33

Appendix 1: Mentoring programs and its impact 33

Appendix 2: Study design and methodology 34 



\section{ACKNOWLEDGEMENTS}

Department for International Development (DfID) aims to improve the lives of adolescents, women and the poor people of the developing nations including Bangladesh. Financial literacy programs are one of the avenues to bring such changes. We are grateful to the DfID Bangladesh for sponsoring the pilot study and endeavor to write a white paper to set the discourse and futures of the financial literacy programs for Bangladesh. Barbara Payne, Senior Education Advisor, and Fazle Rabbani, Advisor, DfID, played key role in initiating the study.

The Council began the financial literacy discourse through a consultative workshop on August 30, 2009. We are grateful to Dr. Wahiduddin Mahmud, Professor of Economics, Dhaka University, for chairing the workshop and inspiring to develop appropriate financial literacy programs. We sincerely thank Sayyied Kabir, Economic Consultant, and M. Mahbubul Huq, Executive Director, Chittagong Skills Development Center, for moderating interactive group discussions. Population Council extends heartfelt thanks to Farah Mehreen Ahmad, Material Developer, SoFEA, BRAC, Syeda Obaida Haque, Senior Director- Program, Shakti Foundation, Brigadier General Aftab Uddin Ahmed (Retired), Executive Director, Underprivileged Children's Educational Program (UCEP) and Dr. Muhammad Ibrahim, Executive Director, Center for Mass Education and Sciences (CMES) for sharing their experiences related to adolescent life skills and financial education programs.

For insightful comments on implications for financial education programs in Bangladesh- we are thankful to the expert panelists-Aftab Uddin Ahmed, UCEP Bangladesh, Rashida Parveen, Head of Adolescent Development Program (ADP) of BRAC, Dr. Erum Mariam, Director of Institute of Educational Development, BRAC University, Isthiaq Mohiuddin, Director of BRAC Micro-finance, and Dr. M.A. Baqui Khalily, Professor of Finance, Dhaka University- at the dissemination workshop held in Dhaka on August 18, 2010.

For actively participating in the workshop and offering inputs in shaping the future financial education program in Bangladesh, we express our heartfelt thanks to the representatives from the Department of Youth Development and Ministry of Youth and Sports of Government of Bangladesh, Bangladesh small and cottage industries corporation (BSCIC); and financial institutes, NGOs and development partners including Action Aid Bangladesh, Anukul Foundation, Assistance for Slum Dwellers, Bangladesh Institute of Bank Management, Bangladesh-Korea Technical 
Training Center, BRAC Bangladesh, BRAC Development Institute, BBC-English in Action, Campaign for Popular Education, CMES, CARE Bangladesh, Dhaka Ahsania Mission, Dhaka University, Embassy of the Kingdom of Netherlands, Grameen Shikkha, ICDDR,B, Micro Industries Development Assistance Society, Marie Stopes Clinic Society, Nari Maitree, Padakkhep Manabik Unnayn Kendra, Palli Karma-Sahayak Foundation, PIACT Bangladesh, Research Training \& Management, Sajida Foundation, Save The Children USA, Save The Children UK, Shakti Foundation for Disadvantaged Women, The Institute of Cost and Management Accountants of Bangladesh, University of Liberal Arts Bangladesh, UCEP Bangladesh, and United States Agency for International Development.

Implementing partners, ADP of BRAC and technical institutes of UCEP, deserve special credit for successfully implementing the financial education program using the standard teaching and innovative mentoring approach. Kaniz Fatima, Advisor, BRAC and Dr. Safiqul Islam, Director, Education Program, BRAC, and Brigadier Ahmed of UCEP Bangladesh offered guidance in implementation. In facilitating the implementation, we like to specially mention contribution of Rashida Parveen, Marzina Khatun, Najneen Mahbooba, Wahida Ifat, Khurshida Jahan, and Mitali Das of BRAC; and Md. Mohiuzzaman, Md. Habibur Rahman, Eng. M. A. Mannan, S.A. Saleh Ahsan, K.M Saleheen, and Engr. M. Ayub Ali Sarkar of UCEP.

We are immensely greatful to the teachers, mentors, mentor coordinators of BRAC and UCEP; and hundreds of students of UCEP technical schools and Adolescent Club members of BRAC for actively participating in the financial educaton sessions, taking part in the survey and giving suggestions on implemenation and improving the future program.

Our sincere gratitude to Dr. Wendy Baldwin, Vice President of Poverty, Gender and Youth Program of the Population Council for reviwing the draft white paper and making insightful comments. Lastly, we are thankful to the Council staff - Md. Moshiur Rahman, Farhana Akter, Md. Mostafizur Rahman Khan, Kazi Tamanna Keya, Eshita Jahan, Nondini Lopa, Nargis Sultana and Sareeta Haider for their inputs in the program development and implementation; and Dipak Kumar Shil, Mamun-ur-Rashid, Joynal Abedin, Mursheda Rahman for their cooperation in administration and financial aspects of the study. 
ACRONYMS

$\begin{array}{ll}\text { ADP } & \text { Adolescent Development Program } \\ \text { AGP } & \text { Adolescent Girl Program } \\ \text { AIDS } & \text { Acquired Immune Deficiency Syndrome } \\ \text { BAS } & \text { Bangladesh Adolescent Survey } \\ \text { BSCIC } & \text { Bangladesh Small and Cottage Industries Corporation } \\ \text { CMES } & \text { Center for Mass Education and Communication } \\ \text { DfID } & \text { Department for International Development } \\ \text { DPS } & \text { Deposit Pension Scheme } \\ \text { ELA } & \text { Employment and Livelihood for Adolescents } \\ \text { FAO } & \text { Food and Agricultural Organization } \\ \text { GFEP } & \text { Global Financial Education Program } \\ \text { HIV } & \text { Human Immune-Deficiency Virus } \\ \text { IMF } & \text { Institute of Micro Finance } \\ \text { ILO } & \text { International Labor Organization } \\ \text { MFI } & \text { Micro Finance Institutes } \\ \text { NGO } & \text { Non-Governmental Organization } \\ \text { SoFEA } & \text { Social and Financial Empowerment of Adolescents } \\ \text { SPSS } & \text { Statistical Package for Social Sciences } \\ \text { SEWA } & \text { Self-Employed Women's Association } \\ \text { SWOT } & \text { Strengths, Weaknesses, Opportunities and Threats } \\ \text { UCEP } & \text { Underprivileged Children's Educational Program } \\ \text { UKaid } & \text { Aid from the United Kingdom }\end{array}$




\section{PARTNERS - AT A GLANCE}

POPULATION COUNCIL

The Population Council is an international, nonprofit, nongovernmental organization that seeks to improve the well-being and reproductive health of current and future generations around the world and to help achieve a humane, equitable, and sustainable balance between people and resources. The Population Council's work ranges over the broad field of population: from research to improve services and products that respond to people's reproductive health needs to designing interventions to treat and prevent HIV/AIDS and other sexually transmitted diseases; from studies of the effects of population factors on a country's ability to provide a better life for its citizens to research that investigates the influence of education and livelihood opportunities on young girls and women. The Council is concerned with the reproductive health and well-being of the one billion adolescents in the developing world who are about to enter their reproductive years and whose behavior will shape the future of their countries. Please visit http://www.popcouncil.org/ for more information.

\section{UNDER-PRIVILEGED CHILDREN'S EDUCATIONAL PROGRAM (UCEP)}

UCEP is a Bangladeshi non-governmental organization that provides alternative education opportunities for working children with an objective to improve their socio-economic condition by upgrading their skills and providing better job opportunities. It works primarily with working children living in urban slums, shanties and squatter settlements. UCEP's activities are concentrated in the cities of Dhaka, Chittagong, Khulna, Sylhet, Barisal and Rajshahi. While it provides general education in all this six metropolitan cities, it offers vocational education through its technical schools located in Dhaka, Chittagong and Khulna. Please visit http://www.ucepbd.org/ for more information.

\section{BRAC ADOLESCENT DEVELOPMENT PROGRAM}

The Adolescent Development Program started in 1993, rising out of BRAC's school for older children. BRAC was incorporated as a development organization in 1972. The ADP program rose out of a need to help BRAC school children retain the literacy numeracy and life skills that are lost after primary schooling. The Adolescent Clubs provide the chance to socialize, play indoor games, sing, dance and exchange views and experiences. In addition to providing adolescent clubs (Kishori Kendro) the program offers life skills and livelihoods training to its members. By 2010 nearly 250,879 girls and 62,000 boys were counted as members in 8,772 adolescent clubs. Please visit http://www.brac.net/content/adolescent-development-programme for more information. 


\section{EXECUTIVE SUMMARY}

This white paper addresses a growing concern about the problems of financial exclusion of the poor. It is based on a scoping study and a pilot program experimenting with new techniques of providing financial education among adolescents in Bangladesh. Working with two highly successful Bangladeshi institutions, the Population Council worked to expand lifeskills and livelihood skills through financial education in urban and rural Bangladesh. The institutions are BRAC and Underprivileged Children's Educational Program (UCEP). These programs have collaborated with Population Council for varying lengths of time in collaborative action research projects to address young peoples' need for skill acquisition.

The school to work transition program that we piloted has a primary focus on experimental techniques to impart financial literacy and financial skills required for successful entry into gainful and productive work. In particular, we are interested in exploring the potential of alternative pedagogic techniques to classroom teaching and techniques that allow young people to watch and learn through mentoring relationships, internships or apprenticeship.

Bangladesh is at a juncture in terms of its development in the financial sector that will respond positively to fundamental investments in promoting financial education. An investment in the education of large cohorts of young people over the past couple of decades, girls in particular, has created a cohort of students eagerly poised for a productive life. In the absence of such investments there is a real and imminent danger of a missed opportunity, both in terms of the risk of creating the largest ever cohort of frustrated and underemployed youth and missing the potential of opportunities created by financial innovations and a thriving banking sector.

The repeated national dialogues and the scoping study underscored the need for financial literacy for all ages, especially among the adolescents. The pilot test indicated short-term outcomes in terms of financial education, attitudes and behaviors. However, pedagogical techniques - mentoring and teaching approach- did not vary in the short-term but mentoring approach has potential to impact in the 
long run on the impact indicators. The financial education did not have any impact on other domains of health, education, and sexual and reproductive health over the short span of time. Longer follow up and exposure may be necessary to observe and capture intermediate and long-term outcomes.

The result and tools of the study inspired UCEP to commit introduction of financial literacy in 52 schools for the under privileged children from next year while BRAC expressed interest to accumulate resources and initiate discussions with their donors and consortium partners for gradually introducing the financial literacy in 8,800 adolescent clubs all over Bangladesh. Such expansion of financial literacy will give scope to evaluate the impact of intermediate and long term outcomes of the financial literacy programs with long-term prospective study design. Given the needs and the opportunities that lie ahead, the financial education curriculum can be tweaked into different doses, and customized to reach much wider group of audience including but not limiting garments workers, micro-finance clientele, skill development institutes; and gradually into the country wide formal and non-formal education systems. 


\section{INTRODUCTION}

A common misperception about finance is that one needs to know about financial management only when there is a lot of money to manage. Yet, there is abundant evidence that even "...money is equally important to those who have it and those who don't'

the poorest have complex strategies and portfolios and engage in multiple strategies to maintain even a subsistence level of living (Rutherford, 2000) Poor adolescents in developing countries share the same goals as all people - economic security for themselves, their families, and their future. The main difference is that they have fewer resources and opportunities, and, compared to others, they don't have much money. In this context, managing the little money that they have is vital. Good money management is critical for meeting day-to-day needs, dealing with life cycle events, unexpected emergencies, and planning for the future.

\section{OBJECTIVES}

This white paper identifies issues surrounding the development of financial capabilities. It is based on a desk review of relevant literature, curricula and programs, and reports on a pilot program to test new methods of providing financial education to adolescents in Bangladesh. The objective of the paper is to engage policy makers, program managers, researchers and other stakeholders in a discussion of the scope, limitations, and probable way forward in promoting financial capabilities to ensure financial inclusion of the poor. The strategy of choice is programmatic evidence generation to enhance financial education and skills for poor women and adolescents in Bangladesh. 


\section{RATIONALE}

\section{Why financial education?}

In Bangladesh, several recent developments have made available a myriad of financial options. First, thanks to the considerable presence of micro-finance institutions (MFI) and their outreach programs for the poor, even the most economically disadvantaged households have a range of savings and loan choices. Second, recent deregulation of the financial sector has led to the proliferation of private banks, a field once dominated by a handful of public sector banks. Third, Islamic banking has become one of the fastest growing segments of the global banking sector. As part of the liberal banking environment in Bangladesh, Islamic banking has proliferated. Islamic banking poses some new challenges because of its distinct banking ethos and accompanying nomenclature. For example, since interest is not allowed ("baram"), returns to investments are described in "...Young people in Bangladesh and
the UK may differ in financial practices
in terms of savings and borrowing, but
given the economic volatility and
competition, both need to enhance
their financial capabilities."
Barbara Payne, DfID Bangladesh terms of profit.

It is widely recognized among programmers that it is important to start young. In Bangladesh, of necessity the poor become financially active at an early age. Accordingly, vocational training programs and entrepreneurship building efforts are undertaken to increase young people's entrepreneurship and income generation capacity.

Financial capabilities can have wider social impact beyond poverty. While it has long been known that poverty, education and other indicators of socio-economic status are correlated with better sexual and reproductive health outcomes and lower risky sexual behaviors for instance, two recent studies have provided convincing experimental evidence of how randomly assigned programs to enhance financial skills and economic independence can have wider social impact. In Malawi a cash 
transfer program demonstrated the importance of economic self-sufficiency in reducing the risky sexual behavior (Baird, 2009) In South Africa adding a financial education component to life-skills resulted in significantly greater positive impact in changing sexual behaviors (Hallman 2010). Thus, financial education has scope to have positive impact on sexual and reproductive health, and educational outcomes mediating through life skills, income generation, and asset building.

The global financial crisis, the early engagement of adolescents as economic actors, rapid globalization and changes in the financial sector and the absence of an effective strategy for providing financial education have brought into focus the need to develop context and culturally relevant financial literacy program for the poor adolescents and women in Bangladesh.

\section{Why poor women?}

There is a specific need to enhance the financial capabilities of women. Over ninety percent of all microfinance borrowers are women, yet because of their traditional

"Loans are widely available for poor women in Bangladesh, but they often lack the knowledge to use loans properly."

Syeda Obaida Haque, Shakti Foundation exclusion from markets and from asset ownership, women often lack the skills or knowledge to make well informed financial decisions. This is most strikingly evident among garment workers who have been pioneering in many ways. Garment workers are a first generation of migrant women who have moved from their rural homes to urban factories enticed by opportunities in the fast growing sector. Several studies have shown that while workers are intense savers very few of them have access to secure saving opportunities. Instead they rely on family and friends to bank their money. Those they turn to for safekeeping are often predatory middlemen who provide access to an informal financial economy (Amin 1998). Yet, particularly in poor and female headed households, women often assume responsibility for household cash management under difficult circumstances with few resources to fall back on. 


\section{Why adolescents?}

The time to educate women to become strong and financially independent is when they are younger so that they can learn the lessons, and apply them; this is the reason why it is important that the program reaches adolescent girls and young women (Young Women's Financial Network 2006). We need to ensure that the next generation of women is able to be financially independent so that they in turn can empower the future generation of women. In Bangladesh, most adolescents become active economic "Adolescent girls' social awareness alone is not enough. We started adolescent clubs only incorporating safe space and social awareness program, but gradually incorporated livelihood programs, as they want to be economically empowered."

Rashida Parveen, BRAC ADP

players at a young age and more so when they are poor. More than two-third young people of 20-24 year age group are involved in some form of economic activity. Financial literacy is a particularly important building block for adolescents and young people in developing country like Bangladesh because they often start to work at a young age out of economic necessity. In poor households, adolescents often take on financial responsibilities. Adolescence is a critical time for learning basic skills related to earning, spending, saving, and investing money. However, most adolescents (and adults) learn these skills through trial and error.

\section{SCOPING STUDY ON ENHANCING FINANCIAL CAPABILITIES IN BANGLADESH}

Based on recent experience of programs to enhance financial skills as part of a broader livelihood strategy, the Population Council, with the support of Department for International Development (DfID), embarked upon a scoping analysis and needs assessment. The components included (i) secondary analysis of existing data; (ii) qualitative study including focus group discussions and in-depth interviews with young women and key informants in their communities and schools; and (iii) consultative discussions with practitioners and experts to assess the current status of 
and need for enriching financial capability through education and training for adolescents in Bangladesh.

Scope for financial education in Bangladesh: Evidence from the secondary data

In order to assess the scope for financial education for young people we undertook an analysis of secondary data from the Bangladesh Adolescent Survey (BAS) 2005, a nationally representative survey of adolescents and youth 10 to 24 years old. Half the sample was currently in-school and 10 percent had never attended school.

With regard to the financial behaviors, about one in ten adolescents received loan but borrowing rises significantly with age (Figure 1). Women are slightly more likely than men to engage in borrowing and savings perhaps because while their needs are there, they do not have the same labor force opportunities as men (Figures 1 and 2). The overall proportions working to earn an income, borrow and save masks an important age related trajectory (Figure 2). Most young people become active in adult roles at relatively young ages and by the ages of 18 are as likely to work, borrow and save as adults in their community.

Figure 1. Income generating activities, loan and savings by gender in percent (Bangladesh Adolescent Survey 2005)

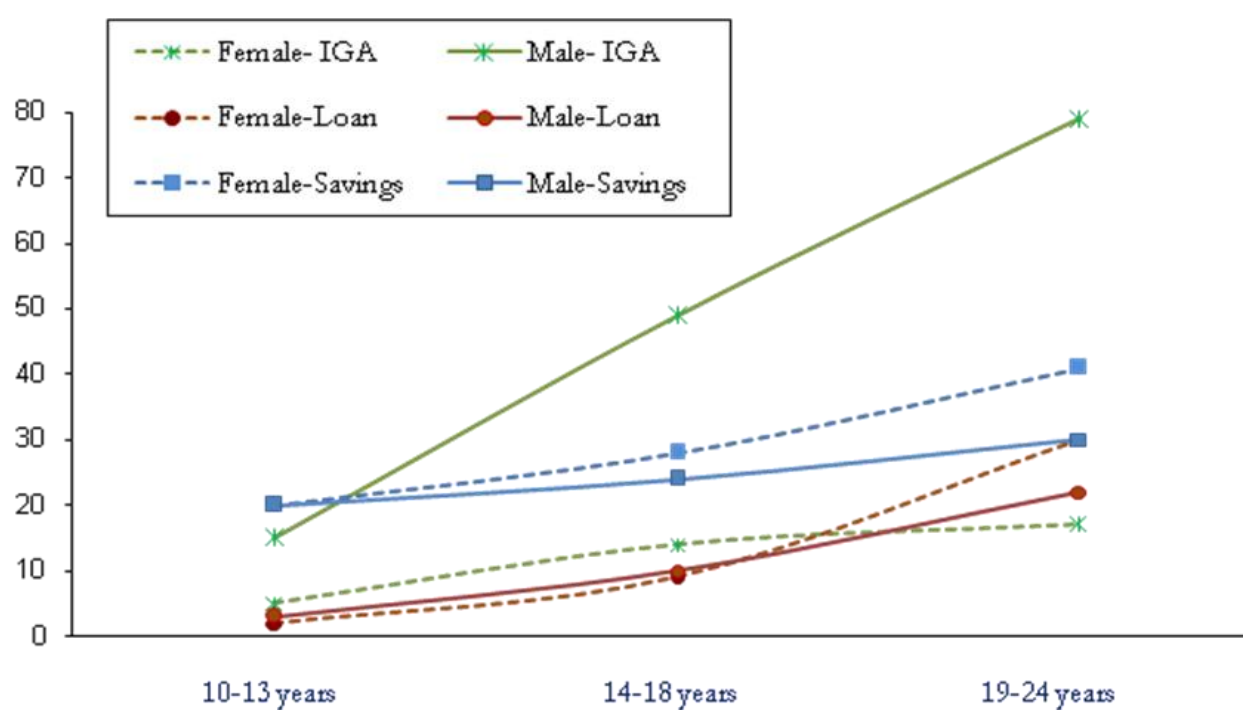


A little over one-fourth of the respondents $(n=4,010)$ reported savings with mean savings of Taka 3,161 only. The average savings amount increased with age; and the amount was higher for males. About half of the respondents reported keeping savings with the formal and semi-formal financial sectors like banks, cooperatives, post-offices, NGOs and "somitis" (specific groups formed with members identified from certain places, clubs or activities), the rest saved at home with self, their family members or in piggy banks (Figure 2). Gender disaggregated data show that men and women differ primarily in their access to NGOs for purposes of savings. They are equally likely to save at home or with a bank (Figure 2).

Figure 2. Savings options exercised by adolescents and youth by gender (Bangladesh Adolescent Survey 2005)

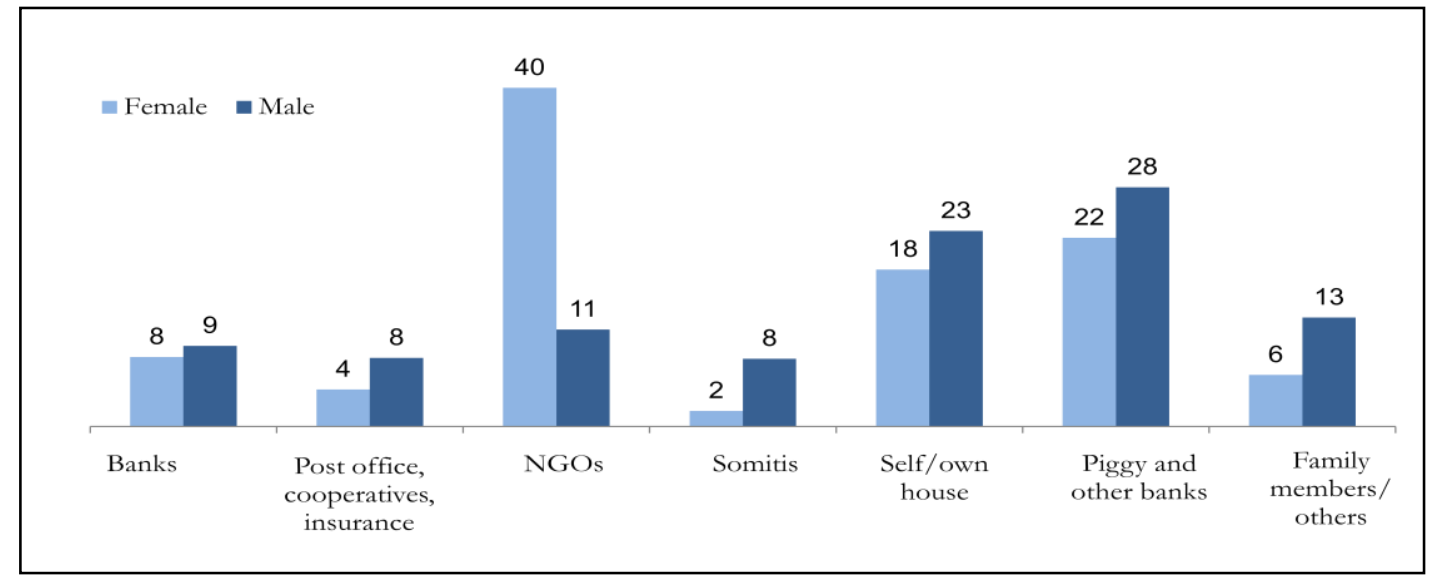

Thus, the financial behaviors reflected in using savings and loan of the adolescents and young people indicated clear need for adolescents and young people to have access to financial literacy, especially about knowledge of savings options, thinking critically to choose the better savings options, and financial opportunities including loan and productive usage of loan, especially in investments and own education.

\section{Scope of financial literacy in Bangladesh: Listening to girls' voices}

A qualitative study conducted on financial education consisted of in-depth and focus group interviews among girls in the age range 14 to 22 to capture the experience of young people as they transit to the adulthood. The focus of the interviews was on 
their financial lives including questions on knowledge, attitudes, behaviors, things they want to learn and ways they prefer to learn. Since we were planning to implement a program in partnership with two existing NGOs with extensive work among adolescent girls, the respondents were selected through these programs.

The lessons learned from the qualitative data are best summarized through discussion of some life histories of young women representing a range of life circumstances. Attitudes towards and circumstances of work are best shown through the example of a few illustrative cases. Shima's situation (Box 1) illustrates the situation of a young woman who work long hours to support her family but neither she nor her family trusts her to manage her own income. This despite having more education, work experience and income than the elders she relies on them to handle her finances.

\section{Box 1: Too young to manage money but not too young to work in a factory} After completing UCEP Technical School, Shima got a job in an electronics manufacturing company in 2007. She works full time earning about Tk. 2,800 a month, and takes grade 10 classes through distance education during evenings and weekends. Shima and her father are the main earners contributing towards the household budget. Her father is a fruit vendor earning about 2,500 taka per month. Shima began working to earn money when she was 13 by taking in piecework in beading and embroidery. Every month Shima hands over her entire salary to her mother. Her mother spends some money for household expenses and deposits the rest in savings. Her mother has decided that Shima's younger sister's education is the priority, and allocates her savings accordingly. Shima has faith in her parents' decision; and thinks she would not be as wise if she were to manage her own money.

Age-20 years, female, employed, unmarried, Dhaka

Snigdha is an enterprising young woman who has continued her education through a failed marriage while she raises her child and runs her own tutoring business. After her marriage ended she came back to live with her natal family. Snigdha feels insecure because such support is a privilege but not a right. Snigdha understands that her child's future depends on her "We should think before spending
money and save for the future." A 22-year old entrepreneur savings. Snigdha is able to save most of her income and prefers saving in a formal institution and for the long term. She believes that having a strong future orientation 
is important for all the young people. Her point of view is likely colored by her particular circumstances and stronger than others of her age.

\section{Box 2: Growing up with financial responsibilities}

Snigdha (fictitious name) runs her own tutoring/coaching center for children. She is enrolled in class nine. Snigdha's brothers are the primary earning members of her family. Snigdha is divorced with a seven year old child. She got married when she was 13 or 14, but sought divorce soon after because her husband had a drug addiction. She has no plans to get married again. She is a leader of the BRAC Kishori Club. She started working to support herself while she was still enrolled in class six at the age of 15 as a teacher of BRAC Shishu School. She earns about 1,900 taka per month from her coaching center. She saves in the two Deposit Pension Scheme (DPS) Accounts with the Grameen Bank at the rate of 500 taka and 50 takea each month. Besides this she also saves money in piggy bank and after $1 / 2$ years she spends that money on gold jewelry, and views her jewelry as a form of savings. In order to access the savings account Snigdha had to borrow first from the Grameen Bank. According to Snigdha, if anyone opens a DPS account in Grameen Bank, he/she is bound to take a loan. She took 5,000 taka as loan and gave that to her brothers and her brothers pay the installments for Snigdha. Snigdha's opinion about savings, "we should think before spending money and save for the future."

Age-22 years, female, student, divorced and mother of a child, Tangail

While financial and technical institutions offer credit opportunities for getting selfemployed or expanding business, an emergency family crisis or misuse of the loan proceedings may put young people in a debt. This is evident in case of Momota who took a loan with the intention of starting her own business. When her parents fell ill the money was used for their medical expenses. Momota was compelled to find a factory job instead, and now rather than working for her own business she uses twothird of her monthly income to pay back her loan.

\section{Box 3: Over indebtedness at a young age}

Momota (fictitious name) and her elder brother are the earning members of their family. Momota completed her technical education from UCEP technical school in 2002. Now she is a senior technician of an electronics company and earns 4,500 taka per month. She is studying to sit for the secondary school final examination this year. Momota borrowed 30,000 taka to start a tailoring business from a loan program for graduates. She bought a sewing machine but when her parents fell ill she spent the money on their treatment. Now she is repaying the loan from her salary at the rate of 2,913 taka per month but is yet to start her planned business.

$$
\text { Age-21 years, female, employed, student, Dhaka) }
$$


Scope for financial education in Bangladesh: Consultative discussions with the stakeholders

Consultative discussions with almost 100 stakeholders overwhelmingly underscored the need for financial literacy programs for adolescents and young people in Bangladesh. Given the wide "Keeping record in a written form is the diversity of this group, and first step in financial education." complications involved in teaching financial matters, Prof. Wahiduddin Mahmud the participants outlined the challenges of developing and pilot testing a financial education curriculum.

The consultative exercise identified four issues that could be usefully addressed in order to move forward towards programming in this area:

- Most young people do not receive any formal education to prepare them for adult life with respect to financial responsibilities and decision-making. Program that exist and come close are strictly focused on training young people to be entrepreneurs.

- There is no existing age appropriate curriculum for young adolescents who are not yet prepared to embark upon or utilize entrepreneurship training.

- Changes that have already taken place in the financial sector, and further changes that are likely to occur, highlight the importance of identifying ways to promote financial literacy as a way of increasing capabilities and avoiding economic exclusion of the poor.

- Many young people engage in activities to earn money and save a substantial portion of what they earn, but females do not retain effective control over their income and do not invest their savings in an optimal manner, even within their limited choices.

In this context, Population Council Bangladesh took an initiative for promoting financial education among young people who are at the critical period of their lives. In order to develop a culturally sensitive and effective curriculum, an extensive review of the financial literacy programs and curricula, from around the globe and within the country were done. 


\section{REVIEW OF FINANCIAL LITERACY CURRICULA AND PROGRAMS}

There are a large number of guides and materials available that have been developed in the wake of a global financial crisis. Guides designed for young people are especially focused on financial indebtedness and responsible consumption. While they incorporate many basic principles that could be adapted to financial education in developing economies, they focus largely on managing finances in the context of higher growth economies with more sophisticated and accessible financial institutions and instruments. They cover investing in stocks, bonds, and other formal financial instruments, managing housing mortgages and automobile loans, using credit cards, choosing what kind of insurance to buy, setting up retirement and college funds, devising tax strategies, and writing wills. Few of these books are aimed at the unbanked poor.

In most contexts, however, financial education is not offered as a routine part of general education even though many schools consider it important (Financial Service Authority 2007).

\section{Financial education for the poor}

Self-Employed Women's Association (SEWA) Bank offers financial counseling service for poor self-employed women in India through Project Tomorrow in collaboration with Freedom from Hunger (SEWA 2003). Its purpose is to develop and test a financial counseling curriculum to help participants manage money productively, plan ways to increase assets, address life cycle events, manage risks, and use SEWA Bank products. Through this project, SEWA Bank has set up a training unit and training delivery system and is developing tools and procedures to monitor the counseling work. The project began with market research to assess the needs and demand among SEWA Bank clients for financial education, followed by a training of trainers' course. SEWA Bank is now providing financial counseling to its clients through a weekly course. The initial experience suggests that participants grasp the concepts presented and welcome new perspectives stemming from such training. It has generated a demand for individualized financial counseling services. 
Other exceptional examples of relevant financial literacy tools are developed by World Education and Pact to use as part of literacy training program for rural women in Nepal (Cohen 2003). With these tools, women learn about financial concepts while they learn to read through the Women's Empowerment Program. The Food and Agricultural Organization's (FAO's) Food Security and Nutrition Project in Zambia developed a guide on money management for farmers. It is designed for use by community based field workers and agricultural extension agents to raise issues of money management with families and community groups. While the focus is largely on business planning, record keeping, and managing group enterprise and community projects, it also covers general issues related to cash flow management, tracking income and expenditures, saving, and seasonality (Heney 2000). The next phase of this project will involve the production of a guide that covers a wider range of issues to help people think more clearly about money problems and how to manage them.

In March 2006, Binti Pamoja partnered with the Global Financial Education Program (GFEP) to develop a financial literacy curriculum for adolescent girls (Binti Pamoja Activities, online source, nd). Prior to the drafting of the curriculum, research was conducted with adolescent girls in Kibera, parents, and financial institutions, and then the curriculum was pilot tested with Binti Pamoja members. Alumni of Binti were trained as facilitators of the curriculum and now girls in Binti's core program and the safe spaces are trained regularly on savings, budgeting skills, banking services, and earning money. The global financial education curriculum is also being adapted to local contexts in Bolivia, Peru, Morocco, Nepal, and Uganda.

As part of its program to combat child labor and promote gender equality in Cambodia, the International Labor Organization (ILO) developed a financial education training course for families of child workers (International Labor organization 2008). The ILO course is adapted from the GFEP modules and it lasts for three days (Financial education Update 2008). The course targets primarily women, who are often responsible for managing money in the household. By training women on basic financial skills, ILO believes women will make better 
financial decisions for their families, reducing economic insecurity and indebtedness, two leading causes of child labor in Cambodia. A gender focused adaptation is done showing women in various financial decision making situations such as setting goals, making a family budget, choosing a savings product, deciding whether or not to take a loan for business, and differentiating between funds for family use and funds for business use. Each picture emphasizes the woman's position as a key financial decision-maker. It depicts women making choices about how to manage their money. An additional Content Note was developed about gender equality.

\section{Financial education versus entrepreneurship development}

In Bangladesh, financial education is offered as part of courses on enterprise development in conjunction with vocational training and micro-enterprise initiatives. JOBS developed an educational module called "Amar Bebsha" (my business). The guide uses simple language to introduce the basic components of a small business: costing a product, evaluating demand and supply, pricing, marketing, calculating depreciation, keeping records and accounting (Shahidullah 2003). The materials rely on pictures and charts for semi-literate or illiterate students. Sajeda Foundation's five day training guide for entrepreneurship development and business management has a similar focus on small business development. The training is delivered in classroom teaching method in total contact hour of around 30 hours. Bangladesh Small and Cottage Industries Corporation (BSCIC) has a ten day training module that is similar in content but more extended and includes components on financial plan and strengths, weaknesses, opportunities and threats (SWOT) analysis, organizing and management skill, profit analysis. CMES's entrepreneurship development program as described in the booklet, "If I want to be a businessperson" has been used in CMES's Adolescent Girl Program (AGP). It uses case material and real life examples. The topics are: how to start business, how much money is needed to start business, let's start a production system, dealings with customers, price fixing and changing etc. In addition to business related chapter, one chapter is devoted to environmental considerations and responsibilities such as keeping our physical environment clean and safe from production waste. In 2003 BRAC experimented with an entrepreneur development course for adolescent girls, which was later 
deemed age and education inappropriate for the majority of their members, and abandoned. In addition to the standard entrepreneurship components described above, the course included components on planning, looking for a job and preparing resumes.

The primary contrast between the recommendations of GFEP and the local curricula we reviewed is the emphasis on personal finance in the former and on business or entrepreneurial skill development in the later. The GFEP curriculum is more focused towards changing behavioral aspect of managing money, with emphasis on factors such as distinguishing between good loans and bad loans, indebtedness, needs versus wants, choosing the right product or services from a range of option available etc. In contrast the typical business and entrepreneurship development courses in Bangladesh focuses on how to start a small business, preparing and presenting plans during the process of asking for a loan, as well as general ideas about different kinds of business, situation analysis, preparing marketing and financial plans for starting business.

Among the Bangladesh programs observed and reviewed, BRAC's Aflatoun Program comes closer to the GFEP recommendations of a personal finance oriented curriculum. This is an experimental financial education that instills financial responsibility and savings practice in children young children 8 to 10 years of age. The program began in ten BRAC primary schools at Trishal, Mymensingh with students of grade III and IV and focuses on social financial responsibilities and values. Students also keep record of their savings and spending in a form. The importance of savings is emphasized in classroom teachings and through recitation of rhymes. Students are introduced to the practice of safekeeping and each student receives a small wooden box to store their valuables. Recently, BRAC's SoFEA program has started financial education program with rural women from July 2010; outcome and results are yet come.

\section{Teaching methods}

While most programs use classroom lecture method primarily, several of the courses we reviewed in Bangladesh saw the need to incorporate alternative pedagogies, 
including aspects of mentoring and internship or apprenticeship in their teaching approach. As we observed in our qualitative and quantitative studies, young people are influenced by the adults they observe in close proximity. Role models play an important role in charting out pathways that they can closely observe and learn from (Ray 2004). CMES's initiative uses a combination of classroom lectures and apprenticeship. The first six months is devoted to lectures, and the second six months to apprenticeships in local businesses that CMES helps to set up for their students. CMES monitors the apprenticeship to ensure they are safe and not exploited. During this period students come to CMES once a week and share their experiences what they have learnt.

With the objective of facilitating an easy transition of their students from technical school to self employment, UCEP conduct a 3 day course on entrepreneurship development. This 15 hours course include topics like characteristics of Entrepreneur, types of Business and risks, market analysis, choosing the right business, SWOT analysis, price fixation, profit-loss calculation, collection of capital etc. Like all other previous mentioned course this too is focused on entrepreneurship development and any sort of personal money management skill is absent.

\section{Mentoring - An alternate pedagogy}

The experience of a range of lifeskills programs to enhance livelihood skills among adolescents has demonstrated the effectiveness of mentoring as the teaching method of choice (Amin 2008). Mentorship elements are gaining popularity with the demonstrated success of programs in other domains as well: general education, reproductive health, HIV/AIDS and also in psycho-social wellbeing of adolescents. Perhaps the best known and oldest mentoring program is Big Brother Big Sister in the United States. An extensive evaluation showed positive impact on lives of the children on educational domain as well as their social skill, confidence and delinquent behavior. A Population Council program in South Africa and the Pratham's Balsakhi program in India, experimented with school-based mentoring program and reported significantly improved educational outcomes. In Guatemala and Egypt Population Council documented positive effects of mentoring to improve lifeskills. 


\section{DEVELOPING A FINANCIAL EDUCATION CURRICULUM FOR GIRLS}

The scoping study demonstrated that financial literacy is a relatively unfamiliar and under explored concept in Bangladesh. An important first step in promoting financial capabilities has to be to demonstrate the value of initiatives through pilot programs. Since there are a number of program initiatives for life-skills building and small enterprise development that shares some common elements with the objectives of promoting financial capabilities these programs can be important starting points.

A central challenge is to design programs that are appropriate for semi-literate students. While the rate of school attendance has increased considerably, many schools are poorly equipped and the quality of education is poor. Children can complete primary and even secondary education without gaining functional literacy. This is particularly true for students who are in second chance programs or in poor communities.

Yet, recent developments in the financial sector have meant that young people have to navigate a complex financial environment in order to make successful transitions into adulthood. Their success depends on making appropriate choices in the formal as well as the informal sector. In addition to the formal sector there are a host of options through family, friends, moneylenders, pawnshops and a wide range of informal systems.

Our scoping analysis and our qualitative data suggests that young women and even young girls have high propensities to save. Savings start at an early age and mostly imitate the behaviors they see in their mother and older sisters. It is apparent that the process of trial and error begins at adolescence; therefore, it's important to protect young people from the downside of this process. For girls, retaining control over their own money is an important consideration and a challenge. Yet promoting greater control in a culturally acceptable manner is challenging.

Using several of the above mentioned financial education curriculum as a guide, the Population Council in partnership with BRAC and UCEP developed a 20-hour 
program of instruction. The curriculum targets primarily adolescent girls of age 1419. The curriculum has designed around broad topics: financial values and responsibilities, planning, savings, loan and budget.

Financial values: The program begins with discussions about behaviors, practices and attitudes towards money and expenses. The primary objective of the lesson is to promote an understanding of budgetary constraints and staying within the limits of one's own budget. While these may not be new ideas for many of the students, the worksheet exercises are expected to cast new light and understanding of practices that may occur unconsciously. The series of 3 worksheets works as a tool for the students to think over and realizing the basic financial values; this time consciously.

Planning: Lessons emphasize proactive planning as a key element of preparing for the future. It includes discussion on financial and non-financial planning in life. Lessons in planning include discussion of possible unexpected emergencies, in relation to anticipated sources of income expenses. Comparison of financial and non-financial planning, such as planning to prepare for a test, helps students learn by analogy. Worksheet exercised also highlight the importance of flexibility and revising expectations in view of constraints.

Savings: Since young people in Bangladesh are familiar with informal and formal savings mechanisms, it is a useful heuristic devise for discussing concepts such as cash-flow management, future planning, accessing formal banking products, and household asset building strategies. Women usually save in NGOs and other semiformal institutions as members. The choice of which group to join thus becomes an important financial decision because membership implies varied entitlements. Savings options are discussed in terms ease of use, safety, interest gained and liquidity. Many of these options are now becoming available at early ages while girls are still in school. In exercises, students are asked to analyze the savings goals and challenges of the actor in the story and select a best possible savings option for him/her. The lessons communicate that while there are no universally right or wrong savings options; individuals need to assess their own financial situation and savings goal. 


\section{Box 4: Snapshots from curriculum- Financial value}

\section{Step 1: Make a wish list.}

Let's play a game. See the items and make a list of things that you would like to buy.

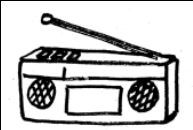

Cassette player

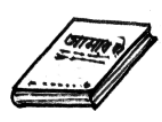

Book

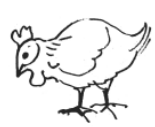

Chicken

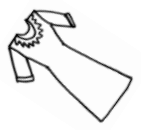

Dress

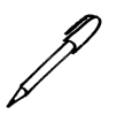

Pen

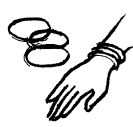

Bangles

Worksheet exercise 2.1:

Things that I want to buy

Step 2: Know your limit.

You have already made your wish list of things you want to buy. Now, assume you have 400 taka at hand; and seeing the prices- would you like to reconsider your wish list?

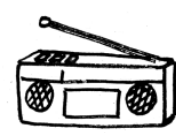

Cassette player 350/-

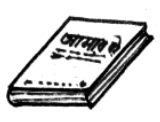

Book 30/-

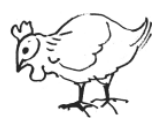

Chicken

140/-

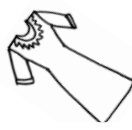

Dress 250/-

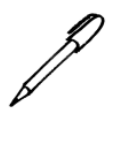

Pen

5/-

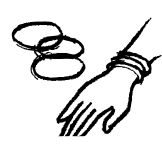

Bangles 15/-

Worksheet exercise 2.2:

Things I would like to buy after knowing the price

Step 3: Revisit the wish list.

What can I afford to buy with 400 taka?

Worksheet exercise 2.3: After knowing the prices of items and 400 taka in hand things that I would now like to buy

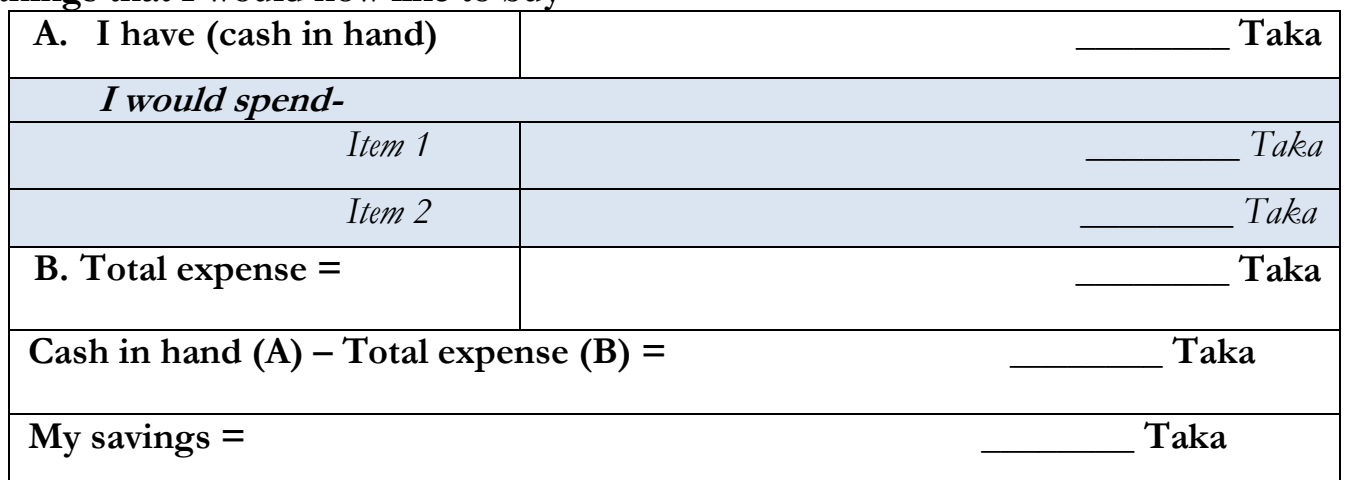


Negotiation skill: This section discusses the role of negotiation skills in everyday life and how they can be applied to conversations about money. Participants analyze examples in real life vignettes. Examples include not just negotiating with financial service providers, but also with clients, neighbors and even with their family members, which is especially important for girls. Asking her parents for money, or trying to save her savings, bargaining for things at the market, or discussing with friends about who will pay for what are all examples of financial negotiations. The lessons then go on to applying the relevance of core negotiation skills in other aspects of life.

Borrowing: With the easy access of collateral free loans from different NGOs and MFIs, especially to women, it is important for them to understand the terms of loan and be aware of the chain of multiple loans and its consequences. As women gets loan easily it is very common to take loan against her name and that loan is used by other family members- for business of brother, husband or even relatives. In many cases, that woman has no control of maintaining schedule of loan repayment. And she does not even understand the terms and conditions. Calculation of amount of interest and knowing the terms and conditions of loan, comparing among different loan options, thinking over source of repayment beforehand- these topics are very relevant and necessary for informed financial decision making.

Budget: Budget is a part of planning and budget helps to redefine ones' plan when necessary. A budget gives a summary of estimated income and expenses, including savings, over a period of time (for example a week or month). In this way, budget aids in planning for spending and saving money in a more concrete way and is a necessary part of financial education. A budget helps the girl to make decisions about how much money she can spend; and allow her to take control of her money and serves as a guide to help her to live within the income. If her earnings do not cover her expenses, her budget will make it easier for her to identify which expenses to cut back when all are listed together. 


\section{DEFINING MENTORING IN FINANCIAL EDUCATION}

In an attempt to identify an alternative to the traditional method of teaching in classrooms in lecture format, where strong hierarchical relationships often act as a barrier to classroom exchanges, we conducted a mentor dependent program. In half of the classrooms financial education was offered by mentors rather than teachers to compare two alternative methods of teaching.

The design of the mentoring program was based on long discussions with implementing partners and experts about identifying characteristics of good mentors, creating "Mentoring program needs to be designed keeping in mind of the potential exploitation in unstructured mentoring or apprenticeship program." suitable environments for productive engagement and exchange and about the learning process. To address some of the concerns about implementation and the risks of an entirely unstructured set of interactions, a group mentoring approach has been adopted where each mentor is tagged with 5-6 girls and they form a mentor group. Providing further structure, each topic is learned by the participants in a cycle of three classes:

\begin{tabular}{|c|c|c|}
\hline \multicolumn{3}{|c|}{ Box 5: Mentoring- how it works } \\
\hline 1. BRAINSTORM & 2. DISCUSSION & 3. ANALYZE \\
\hline -What do I want to learn? & -Interacting with mentor & $\begin{array}{l}\text {-analyzing and synthesizing } \\
\text { information and learning }\end{array}$ \\
\hline -How to extract the idea? & -Knowledge gathering & $\begin{array}{l}\text {-assessing feasibility in my } \\
\text { own context }\end{array}$ \\
\hline & & -informed decision making \\
\hline \multicolumn{3}{|c|}{ One mentor with 5-6 adolescent girls forms a group } \\
\hline
\end{tabular}


Brainstorming: To trigger a critical assessment participants begin with a brainstorming session on each topic. These sessions are designed to allow participants to devise a strategy or approach by discussing among themselves and framing questions which they are encouraged to write down in their workbooks.

Discussion with the mentor: Interacting with a person and extracting useful information is a necessary life skill that is exercised in the second lesson. In discussion session girls actually meet their mentor, discuss questions they have, share their own experiences and try to learn from mentor's life experience. They read the lessons and do the workbook exercises in their own mentor group.

Analysis: Third lesson in the cycle is for analysis of her learning i.e., what have learnt from the content in the book, by doing workbook exercise, sharing experience in mentor group and talking with her mentor. Now in this lesson she will rethink about learning of 3 days cycle and decide what is appropriate for her, what she is going to follow and what not. Finally she will write down her decisions and opinion in the workbook's analysis section. This session effectively works in one's analytical ability which leads to informed decision making.

\section{THEORY OF CHANGE FOR FINANCIAL EDUCATION IMPACTING ON THE ADOLESCENTLIVES}

Financial education presumably may impact on adolescent lives resulting in shortterm, intermediate and long-term outcomes (Figure 3). Programs to promote financial capability are expected to manifest in a process that begins in the short term with increased financial knowledge, and a value orientation with greater acceptance of savings, income generating activities and business. Depending on the pedagogy, financial capabilities may also result in greater self-esteem, self-efficacy, critical thinking, personal communication skills, ability to make decisions, and negotiation skills. Accumulation of savings and use of financial tools like budgeting and recordkeeping behavior are short-term behavioral outcomes of financial education programs. 
Figure 3. Pathways of personal financial education impacting on adolescent lives

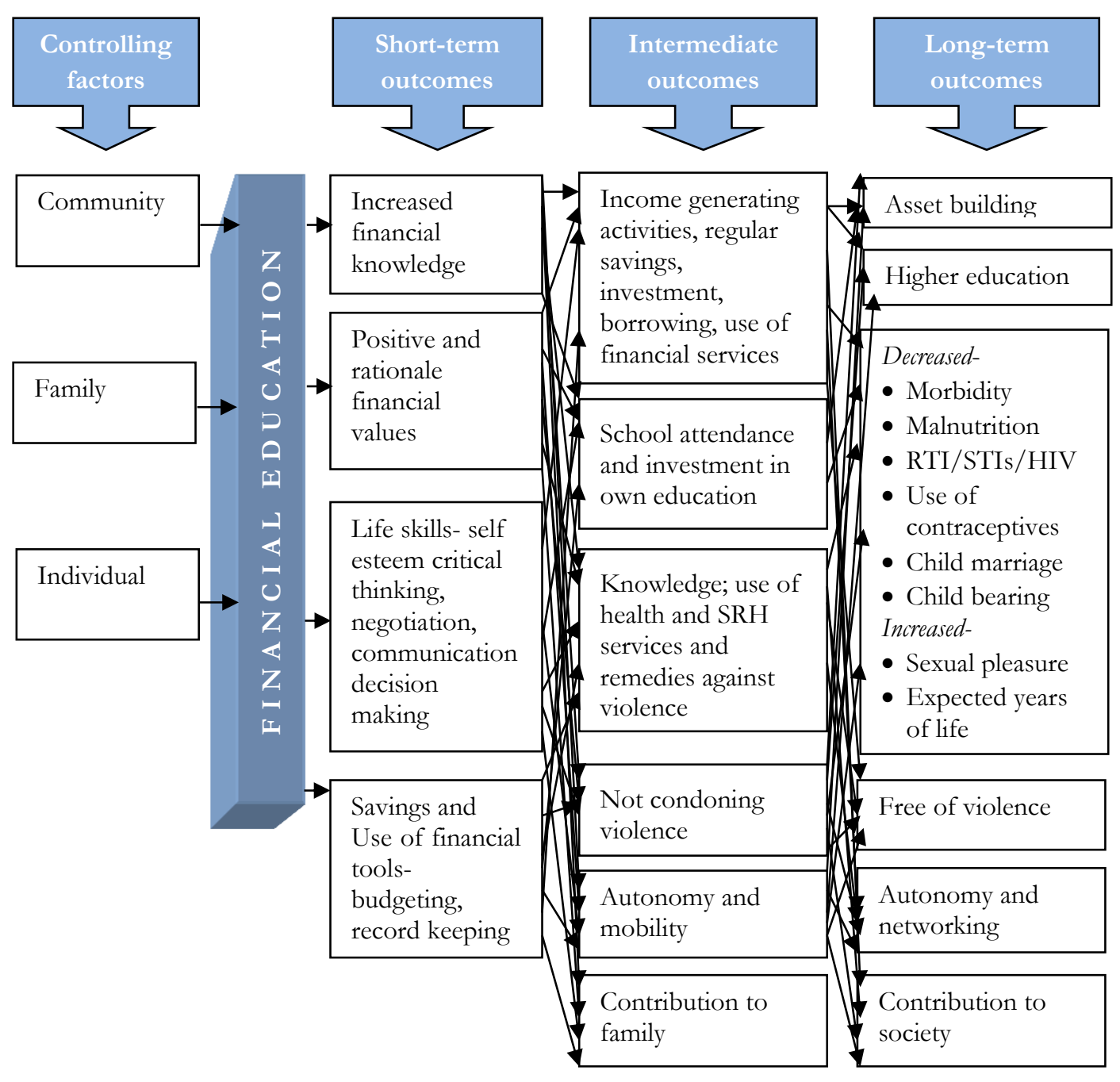


Programs for financial education are also expected to have longer term impact. Mediated through the short term processes, medium term outcomes may include increased income generating activities like involvement in gainful employment, enterprise development; and other financial activities including regular savings, investment and productive borrowing and use of financial services from banks and MFIs. When financial capabilities enhance life skills such as self-esteem and selfefficacy, there can be positive benefits in school performance. Through performance and monetary investment in own education as well as financial autonomy and mobility are likely to improve. Similarly financial education may impact other domains like sexual and reproductive health, and freedom from violence and abuse to the extent they are a function of assets and self-efficacy. These same skills can better equip one to help the family. To the extent that gender discrimination is a function of financial capability certain patterns of gendered behaviors may also change. For instance, an adolescent girl, who used to contribute her entire earnings and savings to the family, may choose to invest in own education or enterprise development.

In the long-run these processes of empowerment may result in asset building, higher education, improved health through reduced exposure to risk and reduced morbidity, malnutrition, reproductive tract infections (RTIs), sexually transmitted infections (STIs) and HIV. Improved access to resources, knowledge, and skills, may reduce the incidence of child marriage, improve use of contraception and delay child bearing. All these will lead to higher level of autonomy, better networking and increased social capital; and enable one to have an improved reproductive health, pleasant sexual and violence free life, and increased expected life years. Finally, success in personal and family lives and possession of better financial and social resources, one would be in a better position to contribute to building a better society. 


\section{PILOT-TESTING A PERSONAL FINANCIAL EDUCATION CURRICULUM \\ Short-term impact of exposure to personal financial education}

Within the time frame and other constraints of our pilot interventions, we expect to observe only the short term effects on financial knowledge, attitudes, and behaviors as measured in a post-test and relative to a pre-test, and the changes are expected to be greater in the intervention sites relative to control sites. The pilot study tested two strategies, a new mentoring approach against the standard teaching method; the changes in the mentoring and the traditional teaching arms are shown separately ${ }^{1}$.

Changes in financial information: The curriculum was designed to enhance knowledge of savings and borrowing options, discerning advantages and disadvantages of financial products, practice of regular and secured savings; and knowledge and practice of budgeting. Knowledge on savings and budgeting increased at both the intervention sites after intervention relative to the preintervention period (Figure 4). However, no significant changes were observed with regard to knowledge of loan options and loan repayment factors (not shown).

Figure 4. Changes in financial knowledge across sites in percent.

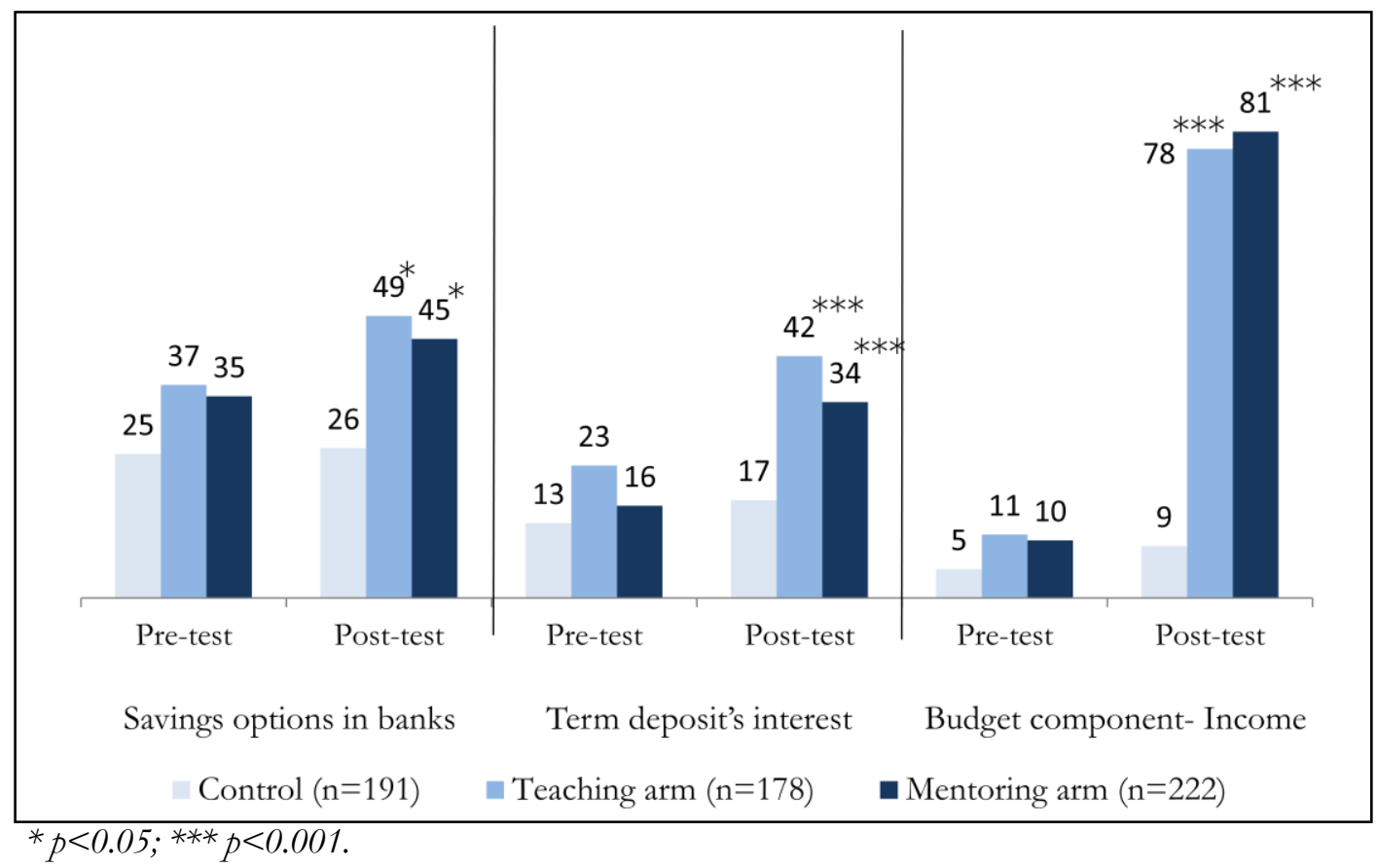

${ }^{1}$ For details about the research design and method see Appendix 
These effects of the program remain after adjusting for location, father's education, mother's housewife status, respondents' marital status, exposure to television and baseline in multivariate analysis. However, the two methods of teaching were not significantly different in their impact on these measures (Table 1).

Table 1. Effects of exposure on financial knowledge in odds ratio

\begin{tabular}{lrrr}
\hline Outcome measures & $\begin{array}{r}\text { Teaching arm } \\
\text { (Ref: control) }\end{array}$ & $\begin{array}{r}\text { Mentoring arm } \\
\text { (Ref: control) }\end{array}$ & $\begin{array}{r}\text { Mentoring arm } \\
\text { (Ref: teaching) }\end{array}$ \\
\hline Savings options in banks & $2.8^{* * *}$ & $2.4^{* * *}$ & $\mathrm{~ns}$ \\
$\begin{array}{l}\text { Term deposit gives higher } \\
\text { interest than general savings } \\
\text { account }\end{array}$ & $3.8^{* * *}$ & $2.8^{* * *}$ & $\mathrm{~ns}$ \\
$\begin{array}{l}\text { Income is one of the budget } \\
\text { components }\end{array}$ & $40.8^{* * *}$ & $55.1^{* * *}$ & $\mathrm{~ns}$ \\
\hline
\end{tabular}

*** $p<0.001$. Ref: reference category; $n s-$ non-significant; $n=591$.

Note: Odds ratio for teaching and mentoring columns have control as the reference category while teaching versus mentoring column has teaching arm as the reference category. Logistic models have been adjusted for location, father's education, mother's housewife status, respondents' marital status, exposure to television and baseline value of the outcome variables.

Changes in financial values and attitudes: Financial values and attitudes often guide the behaviors and practice. Positive values with regard to adolescents' necessity to set and pursue financial goals, save regularly and know about budget increased significantly at both the intervention sites after exposure to intervention (Figure 5).

Logistic regression models adjusted for location, father's education, mother's housewife status, respondents' marital status, exposure to television and baseline value of the outcome variables revealed higher likelihood of increased positive financial attitudes and values at both the intervention sites, but changes did not significantly vary across the two strategies (Table 2). 
Figure 5. Changes in financial attitudes and values across sites in percent.

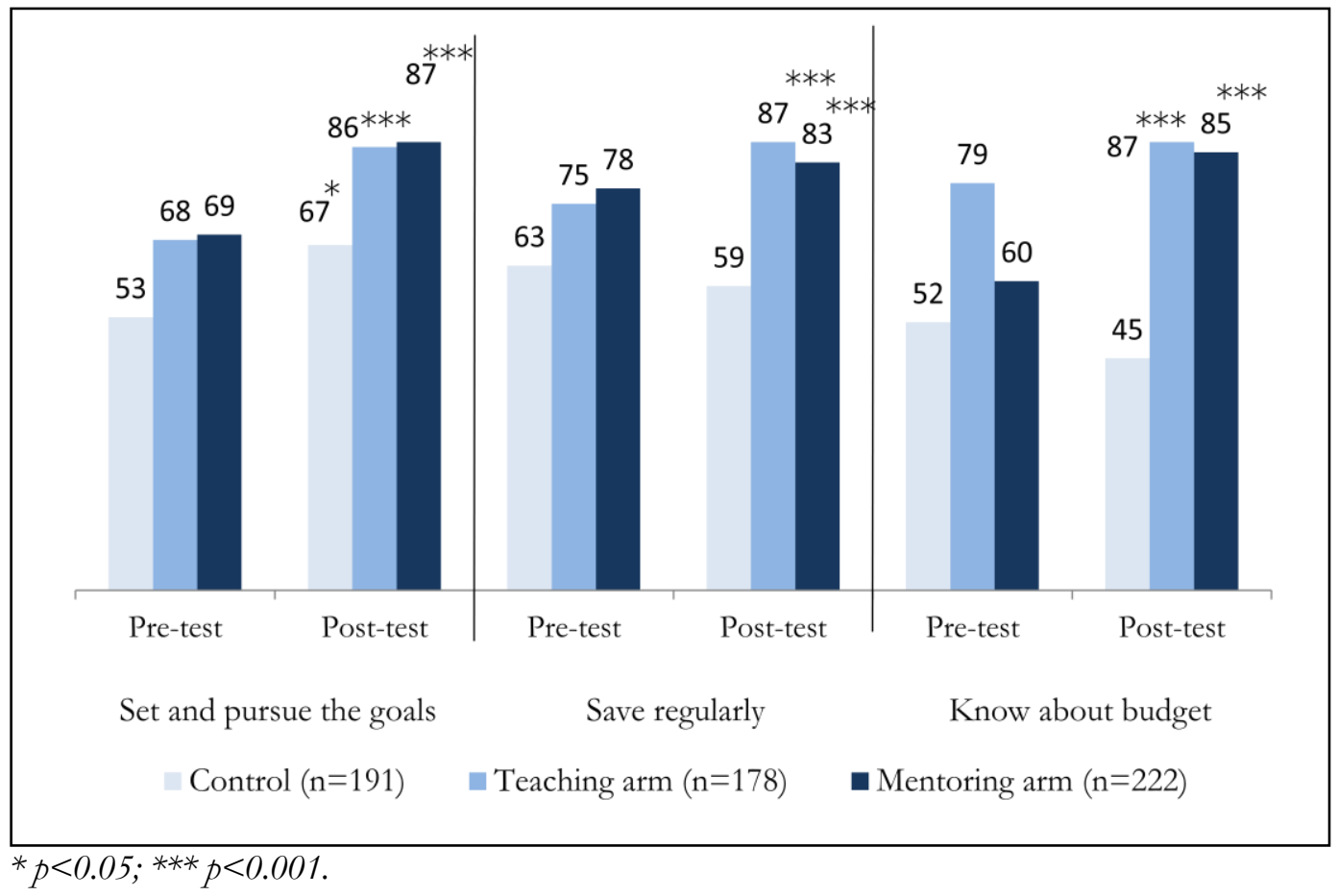

Table 2. Effects of exposure on financial values and attitudes in odds ratio.

\begin{tabular}{lrrr}
\hline Outcome measures & $\begin{array}{r}\text { Teaching arm } \\
\text { (Ref: control) }\end{array}$ & $\begin{array}{r}\text { Mentoring arm } \\
\text { (Ref: control) }\end{array}$ & $\begin{array}{r}\text { Mentoring arm } \\
\text { (Ref: teaching) }\end{array}$ \\
\hline Set and pursue the goal & $3.3^{* * *}$ & $3.6^{* * *}$ & $\mathrm{~ns}$ \\
Save regularly & $4.8^{* * *}$ & $3.3^{* * *}$ & $\mathrm{~ns}$ \\
Know about budget & $8.1^{* * *}$ & $6.7^{* * *}$ & $\mathrm{~ns}$ \\
$\begin{array}{l}\text { Know about financial record- } \\
\text { keeping }\end{array}$ & $6.3^{* * *}$ & $3.8^{* * *}$ & $\mathrm{~ns}$ \\
Know about loan & $3.1^{* * *}$ & $3.5^{* * *}$ & $\mathrm{~ns}$ \\
Learn about business & $2.3^{* * *}$ & $2.6^{* * *}$ & $\mathrm{~ns}$ \\
\hline
\end{tabular}

*** $p<0.001$. Ref: reference category; ns- non-significant; $n=591$.

Note: Odds ratio for teaching and mentoring columns have control as the reference category while teaching versus mentoring column has teaching arm as the reference category. Logistic models have been adjusted for location, father's education, mother's housewife status, respondents' marital status, exposure to television and baseline value of the outcome variables. 
Changes in financial behaviors and use of financial tools: The curriculum and the financial education sessions put much emphasis on savings, budgeting and record-keeping. Due to positive changes in knowledge and attitudes on savings, budgeting and record-keeping, changes in relevant financial behaviors were expected to be positive. At both the intervention sites, significantly higher number of respondents reported savings on their own (rather than relying on family members), keeping records of expenditure, and preparation of budget at the post-test survey relative to the pre-test survey while control did not mark any change (Figure 6).

Figure 6. Changes in financial behaviors across sites in percent.

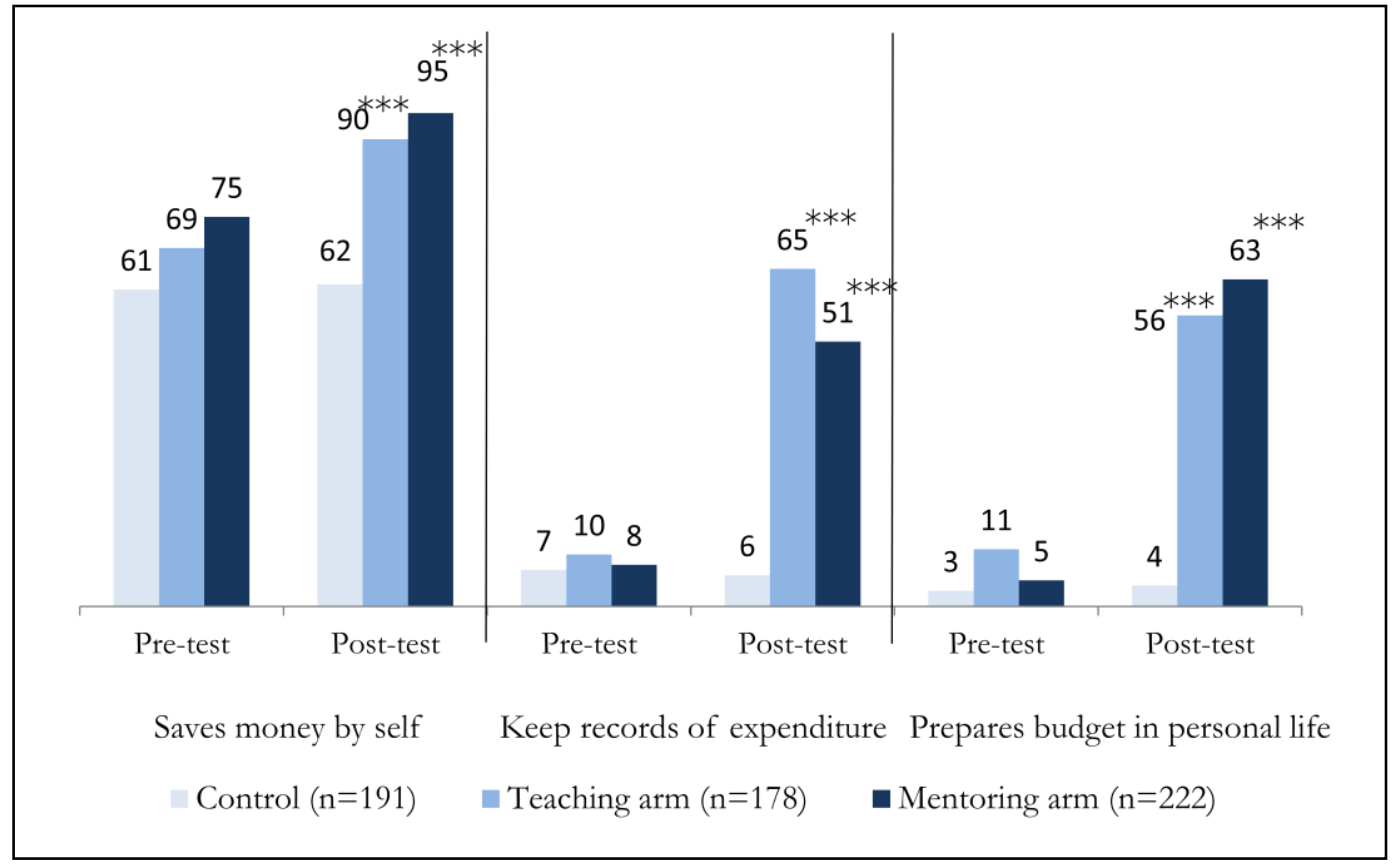

Logistic regression models revealed higher likelihood of increased practice of savings by self, regular savings, use of savings by self, and keeping records of income, expenditure and savings, and preparation of budget in personal life at both the intervention sites (Table 3). Saving regularly, an important aspect of savings practice was almost two times more likely at the mentoring site while practices of savings for own education, and keeping records of income and expenditure were half the time less likely to happen in the teaching arm relative to the mentoring arm (Table 3). 
Table 3. Effects of exposure on financial behaviors in odds ratio.

\begin{tabular}{lrrr}
\hline Outcome measures & $\begin{array}{r}\text { Teaching arm } \\
\text { (Ref: control) }\end{array}$ & $\begin{array}{r}\text { Mentoring arm } \\
\text { (Ref: control) }\end{array}$ & $\begin{array}{r}\text { Mentoring arm } \\
\text { (Ref: teaching) }\end{array}$ \\
\hline Save money by self & $9.8^{* * *}$ & $18.4^{* * *}$ & $\mathrm{~ns}$ \\
Save regularly & $2.8^{* *}$ & $5.4^{* * *}$ & $1.9^{*}$ \\
Use savings by self & $2.7^{* * *}$ & $3.6^{* * *}$ & $\mathrm{Ns}$ \\
Save for own education & $3.1^{* * *}$ & 1.48 & $0.5^{*}$ \\
Keep records of income & $30.5^{* * *}$ & $16.5^{* * *}$ & $0.5^{*}$ \\
Keep records of expenditure & $35.6^{* * *}$ & $21.0^{* * *}$ & $0.6^{*}$ \\
Keep records of savings & $20.5^{* * *}$ & $14.4^{* * *}$ & $\mathrm{~ns}$ \\
Prepare budget in personal life & $33.6^{* * *}$ & $47.4^{* * *}$ & $\mathrm{~ns}$ \\
\hline
\end{tabular}

${ }^{*} p<0.05 ;{ }^{* *} p<0.01 ;{ }^{* * *} p<0.001$. Ref: reference category; ns- non-significant; $n=591$.

Note: Odds ratio for teaching and mentoring columns have control as the reference category while teaching versus mentoring column has teaching arm as the reference category. Logistic models have been adjusted for location, father's education, mother's housewife status, respondents' marital status, exposure to television and baseline value of the outcome variables.

\section{Implications of findings of the trial}

The trial indicated positive impact in short-term outcome variables of financial knowledge, attitudes and practices, as contemplated in the conceptual framework except for changes in life skills (Figure 4). The reason for no change in life skills is due to very high levels of reported self-efficacy even before carrying out the intervention activities. As expected, the financial education did not have any impact on other domains of health, education, and sexual and reproductive health over the short span of time. Longer time periods of follow up and longer term exposure may be necessary to observe and capture intermediate and long-term outcomes. Mentoring arm did not differ significantly relative to the teaching arm. While

"... while our primary focus is on
entrepreneurship development, the
necessity of incorporating financial
education as an integral part of the
entrepreneurship development
cannot be ignored. The successful
implementation of the pilot project
on financial education with the
newly developed curriculum and
mentorship process of teaching has
proved to be effective for our
students."
Brigadier Aftab Uddin Ahmed (Retired),
UCEP


reassuring that mentoring is no worse than teaching, more positive outcomes may be expected with longer term outcomes. Given that much of mentoring is expected to work through the development of interpersonal relationships with mentors, a program with a longer duration may itself do the trick. There is also room for improvement in allowing mentoring relationships to mature so that a mentee can learn by observation as well as by directed interactions. The mentoring approach may need further improvement in terms of increasing the mentoring time or quality of mentors. Overall, the study indicates positive impact of financial education on adolescents' lives, and BRAC and UCEP are poised to incorporate the curriculum in their existing programs with the young people. The MFI has also shown interest to review and customize the curriculum for their clients.

\section{CHALLENGES AHEAD}

In analyzing the prospects of promoting financial capabilities among Bangladesh adolescents we have identified a promising set of tools and methods for promoting financial skills. It is important to recognize that not doing so may present some important risks. The "...two changes are imminent in
Bangladesh-credit bureau and mobile
banking. The microfinance clientele,
including the girls and the youth need
to educate themselves on the financial
issues in order to make informed and
rational decision." Ishtiaq Mohiuddin
Microfinance Institute, BRAC financial sector is changing in profound ways with introduction of credit bureau, "...the young people will be
actively involved in flourishing
micro enterprise sector in future.
As such, they need to have
sufficient knowledge on financial
aspects of micro enterprise
business."
Professor M.A.Baqui Khalily
Dhaka University mobile banking, and myriads of financial products, and in a manner that has great potential but can also come at costs to those who are not appropriately prepared to take advantage. Programs that address financial capability in some form in Bangladesh generally emphasize entrepreneurship development and 
management. However, certain basic skills are a requisite for people in all walks of life. These courses usually teach participants how to track business income and expenditures and/or how to manage loan repayments. Few programs pay attention to issues related to managing personal and household finances or making strategic investment or financial decisions. While increasing financial capabilities of poor and youth through vocational training and entrepreneurship development serves an important need and hold promise they are not universally relevant. Personal financial capability has two appealing features: first everyone can benefit from personal financial management skills in some form even if they do not envision themselves as managers or businessmen. Skills acquired through these courses can be useful in the future when young people do engage in business enterprise, employment or self-employment activities. In economic terms, such financial capabilities are fungible. Nevertheless, promoting financial education in Bangladesh still poses many challenges:

- There is a need to explore the potential for integrating financial literacy into various types of development programs: microfinance, vocational education, skills development, garment workers, life skills classes, school curriculums, non-formal education, and other non school-based programs for youth. The content of the curriculum have to be adapted according to the time, literacy level, age of the receivers.

- There is a need to develop educational material that are accessible to illiterate participants, with a greater reliance of alternative and multiple modes of communication such as audio, video or pictorial depictions.

- A central cultural challenge in talking about personal finance and individual "... mentoring as an alternative method is very effective. Socially and culturally we already have this concept; usually we hear adolescents saying 'boro Apa ba boro Bhai ki bolay ba ki kore ta kora' younger ones tend to follow what an elder sister or brother is doing)."

Dr. Erum Marium, BRAC Development Institute learning and responsibility is the identification of the self as a distinct entity from 
family when the corporate familial identity still remains the norm. Thus the notion of women retaining control over own money is critical issue that may sometimes appear at odds with the culture, more so at the early stage of life.

- The culture of hierarchy in schools poses another kind of cultural challenge. We have proposed the development of mentoring relationship as an alternative to the hierarchical teacher student relationship to reduce the social distance between mentor and mentee. However developing mentoring relationships pose their own challenges in a structured programmatic setting:

- Success of mentoring lies on their mutual trust and how much they can interact with each other. Interaction in more public social places (e.g. playground or park as in the Big-Brother Big Sister model) or in work place of mentor would be a better model.

- Using of competitive games where mentor-mentee can work together as a team to earn more or invest in a real sense can be a more attractive way to learn. It relieves students from abstraction to real life money management experience.

- Without any income generation activity; money management skills seems abstract to some adolescents. Financial education would be more realistic if coupled with livelihood programs.

- Teaching financial capability through mentoring is at least as effective as classroom teaching. We hypothesize, and hope to demonstrate in subsequent studies, that skills acquired by establishing mentoring relationships that are nurtured can also have spillover effects in other domains of functioning.

In Bangladesh, young people are responsible economic actors from an early age-young people are able to work long hours and work hard, and they are able to save a substantial portion of their income. As was shown in a study among "...the young people are an enthusiastic lot.... they have a very good sense of the kind of financial problem their parents are having, the amount of loan they have to pay, who are the loan sharks etc. So there is already a lot of awareness created about financial issues at home." Dr. Erum Marium, BRAC Development Institute garment workers, the propensity to save is strong among all adolescents. The problem is in young people retaining control over their income and exercising such 
control to invest their income. Many factors such as family socialization, cultural obligations, the lack of access to safe savings etc means that savings do not remain within the control of young people. A careful process of introducing financial education components in general education as part of a comprehensive school to work program can have important implications for converting the potentials created by two decades of investments in primary and secondary education to create a productive workforce. 


\section{REFERENCES}

Amin, Sajeda, Ian Diamond, Ruchira T. Naved, and Margaret Newby. 1998. "Transitions to Adulthood of Female Garment-factory Workers in Bangladesh," Studies in Family Planning 29(2):185-200.

Amin, Sajeda. 2008. "Enhancing the benefits of girls' livelihood initiatives," Transition to Adulthood Brief No. 17. New York: Population Council. www.popcouncil.org/pdfs/TABriefs/PGY Brief17 Livelihoods.pdf

Baird, Sarah, Ephraim Chirwa, Craig McIntosh and Berk Özler. 2010. The short-term impacts of a schooling conditional cash transfer program on the sexual behavior of young women. Health Economics, 19: 55-68. doi: 10.1002/hec.1569

Carolina for Kibera. Binti pamoja Activities. http://cfk.unc.edu/binti-pamoja-activities.php

Catino, Jennifer, Marta Julia Ruiz, Kelly Hallman, Eva Roca, Adam Weiner, Alejandra Colom, and Sandra Contreras Aprile. 2009. "For Mayan girls, leadership skills and participation in a national network lead to social, economic, and political gains," Transition to Adulthood Brief No. 5. New York: Population Council. www.popcouncil.org/pdfs/TABriefs/PGY Brief05 MayanGirls.pdf

Cohen, Monique and Jennefer Sebstad. 2003. Financial Education for poor, working paper \#1, Washington D.C. www.globalfinancialed.org/documents/WP1_FinEd4Poor.pdf

Financial Education Update, vol 2, issue 3, spring 2008. www.globalfinancialed.org/documents/Fin $\% 20 \mathrm{Ed} \% 20 \mathrm{Update} \% 20 \mathrm{vol} \% 202 \% 20$ issue $\% 203$.pdf

Financial Service Authority. 2006. Personal finance education in schools: A UK benchmark study www.fsa.gov.uk/pubs/consumer-research/crpr50.pdf

Galbraith, John K. 1975. Money: Whence it came, where it went. New York, Houghton Mifflin.

Hallman, Kelly, Eva Roca, Kasthuri Govender, Emmanuel Mbatha, Rob Pattman, DeeviaBhana, Mike Rogan, and Hannah Taboada. 2010. Siyakha Nentsha" Enhancing the Economic, Health, and Social Capabilities of Highly Vulnerable Youth, Presentation Transcript, Population Association of America, Dallas, Texas. www.slideshare.net/IsihlanguHDA/siyakha-nentsha-enhancing-theeconomic-health-and-social-capabilities-of-highly-vulnerable-youth-4495811

Heney, Jennifer. 2000. "Talking About Money”, A Guide for Community Support Staff Working with the FAO Project improving household food security and Nutrition in the Luapula valley of Zambia.

International Labor Organization. 2008. Financial Education Trainer's Manual. www.ilo.org/wcmsp5/groups/public/---ed_emp/--emp ent/documents/publication/wcms 116165.pdfwww.fao.org/ag/ags/subjects/en/ruralfinance/ pdf/talkingaboutmoney.pdf

Ray, D. 2004. Aspirations, povery and economic change. BREAD policy paper, no 002.

Rutherford, Stuart 2000. The Poor and their Money. New Delhi: Oxford University Press.

The Population council. 2010. Ishraq Newsletter, Issue 1. Ishraq: A second chance program for marginalize rural girls in upper Egypt www.popcouncil.org/pdfs/2010PGY IshraqNews1.pdf

The Abdul Latif Jameel Poverty Action lab. Balsakhi Remedial Tutoring in Vadodara and Mumbai, India. www.povertyactionlab.org/evaluation/balsakhi-remedial-tutoring-vadodara-and-mumbai-india

SEWA. 2003. Financial Education for SEWA Bank members: A facilitator's guide. www.coady.stfx.ca/tinroom/assets/file/resources/abcd/SEWA $\% 20$ Financial $\% 20$ Literacy $\% 20$ Manu al.pdf

Shahidullah, S.M. and Mafruha Alam. 2003. Amar Bebsha. JOBS project, Dhaka, Bangladesh.

Tierney, Joseph P., Jean Baldwin Grossman and Nancy L. Resch. 2000. Making a difference: An impact study of Big Brother Big Sister. Public/private ventures, Philadelphia, USA. www.ppv.org/ppv/publications/assets/111 publication.pdf 


\section{APPENDIX-1}

\section{Mentoring Programs and Its Impact}

\begin{tabular}{|c|c|}
\hline PROGRAMS & OUTCOMES \\
\hline $\begin{array}{l}\text { Big Brother Big Sister, US (Tierney 2000) } \\
\text { A one-to-one volunteer mentoring program to help children reach } \\
\text { their potential and to have a measurable impact on youth. } \\
\text { Beneficiary: Children of ages } 6 \text { through } 18 \text { years known as "Little. } \\
\text { Mentor: Youth of } 18 \text { years of age and older. Known as "Big". } \\
\text { Duration: for at least one hour per week over a period of one year. } \\
\text { Activities: unstructured activities like getting together to shooting } \\
\text { hoops, playing a board game, sharing a pizza, taking a walk in the } \\
\text { park, or just hanging out and talking. }\end{array}$ & $\begin{array}{l}\text { Educational: } \\
\text { - } 52 \% \text { less likely to skip school } \\
\text { - } 37 \% \text { less likely to skip a class } \\
\text {-more confident in schoolwork } \\
\text { Delinquency: } \\
\text { - one-third less likely to hit someone } \\
\text { - } 46 \% \text { less likely to begin using illegal drugs } \\
\text { - } 27 \% \text { less likely to begin using alcohol } \\
\text { Social wellbeing: } \\
\text {-getting along better with their families }\end{array}$ \\
\hline $\begin{array}{l}\text { Ishraq, Egypt (The Population Council 2010) } \\
\text { Provides a safe space for rural out-of-school girls aiming to foster } \\
\text { entry or re-entry into formal schooling with emphasis on enhanced } \\
\text { lifeskill. } \\
\text { Beneficiary: Out of school girls of age } 13-15 \\
\text { Mentor: local female secondary school graduates } \\
\text { Duration: for } 30 \text { months, girls ages } 13-15 \text { met four times a week. } \\
\text { Activities: knowledge and information sharing and playing sports. }\end{array}$ & $\begin{array}{l}\text { Educational } \\
\cdot 92 \% \text { passed government literacy exam } \\
\cdot 68.5 \% \text { entered or re-entered school. } \\
\text { Lifeskill } \\
\text { • Positive gender norm attitudes } \\
\text { •knowledge about nutrition, hygiene, rights \& RH } \\
\text { •desire to delay marriage have a say in choosing a } \\
\text { husband. }\end{array}$ \\
\hline $\begin{array}{l}\text { Abriendo Oportunidades, Guatemala (Catino 2009)) } \\
\text { An empowerment program that teaches girls life, entrepreneurial, and } \\
\text { leadership skills, and provides information about reproductive health. } \\
\text { Beneficiary: Indigenous girls aged } 8-18 \\
\text { Mentor: Female mentor of age } 18 \text { or above. } \\
\text { Duration:Each female mentor leads a club of approximately forty } \\
\text { girls per cycle of } 1 \text { year. } \\
\text { Activities: Workshops and sessions arranged to discuss on self- } \\
\text { esteem, life skills, developing aspirations and plans for the future, } \\
\text { pregnancy prevention, SRH, and HIV/AIDS. }\end{array}$ & $\begin{array}{l}\text { Lifeskill } \\
\text {-new perceptions of the meaning and } \\
\text { consequences of interpersonal, domestic, and } \\
\text { social violence } \\
\text {-able to articulate more ambitious goals for } \\
\text { themselves, such as delaying marriage, returning } \\
\text { to school, and striving to start a small business. }\end{array}$ \\
\hline $\begin{array}{l}\text { Balsakhi, Pratham, India (The Abdul Latif Jameel Poverty } \\
\text { Action Lab) } \\
\text { Is a remedial education intervention running in } 122 \text { public primary } \\
\text { schools in Vadodara and } 77 \text { schools in Mumbai in } 2001 \text {. } \\
\text { Beneficiary: children in the grades } 2,3 \text { and } 4 \text { who were identified as } \\
\text { falling behind their peers. } \\
\text { Mentor/Balsakhi: young women from local community. } \\
\text { Duration: } 2 \text { hours for every school day over a period of } 1 \text { year. } \\
\text { Activities: balsakhi meet with a group of } 15-20 \text { of these children out } \\
\text { of the regular classroom and teach basic literacy and numeracy. }\end{array}$ & $\begin{array}{l}\text { Educational } \\
\text {-Improved overall test scores with biggest gain in } \\
\text { math } \\
\text { - The number of students in the bottom third of } \\
\text { program classes who passed basic competency } \\
\text { tests increased by nearly } 8 \% \\
\cdot 2-3 \% \text { of children in the bottom third could do } \\
\text { long division at the start of the year, but by the } \\
\text { end of the year } 40 \% \text { could in program classes } \\
\text { could compared to } 28 \% \text { in non-treatment classes. }\end{array}$ \\
\hline
\end{tabular}




\section{APPENDIX- 2}

\section{Study Design and Methodology}

\section{Quantitative survey}

Using a pre-test post-test control group design, the Council pilot tested two financial education curricula- one using the mentoring approach and the other employing standard teaching methodover a period of two and half months in May-July 2010. Pre- and post-tests were carried out immediately before and after carrying out the intervention activities. Thus, the pilot study gives the opportunity to test the contemplated theory of change for the short-term outcome variables, as described in the previous section. The curriculums took 15 hours plus 5 hours refresher sessions and used the same content but different pedagogies at the teaching and mentoring arms while the control arm were not exposed to any intervention activity. The curricula were implemented by BRAC and UCEP teachers, mentors and mentor-coordinators in the rural Tangail and urban Dhaka, respectively. The respondents were 14-19 years old females, and members of BRAC adolescent clubs, and students of UCEP technical schools. Informed consent of both parents/guardians and respondents were received before enrolling them into the study. The study protocol was approved by the Council's Institutional Review Board. From a sample of 654 adolescents, a total of 620 enrolled into the study; with 5\% attrition rate, 591 matched respondents took part in pre- and posttest surveys.

\section{Analyses}

In order to understand the characteristics of the respondents, bivariate analysis was carried out. Differences between the pre- and post-tests of the matched sample were measured using the McNemar test; and impact of the intervention strategies was measured using the multi-variate analyses of logistic regression and general linear models. The data were entered using customized offline survey tool; and the analyses were carried out using Statistical Package for Social Sciences (SPSS) version 14.0.

\section{Measures}

A wide range of controlling and explanatory variables as well as short-term outcome variables were included in the study (Appendix A1). Controlling factors included community, household and 
individual characteristics while study arm was treated as the explanatory variable. The arenas of outcome variables included financial knowledge, financial values and attitudes, life skills, financial behaviors, reproductive health knowledge and attitudes towards gender roles and dowry (Appendix A2).

\section{Description of the respondents}

The mean age of the respondents was 15.3 years with about 8 years of schooling. Almost all the respondents were unmarried and currently in school; and half of them were in the technical schools. Mothers' education was about half of that of the fathers whose number of years of education, is, interestingly, almost half of that of the respondents. The socio-demographic characteristics, as depicted in Table 3, indicate that adolescents recruited for mentoring, teaching and control arms are similar in terms of age, education, schooling status, family size and parents' education.

Table A.2.1. Socio-demographic characteristics of respondents by arms

\begin{tabular}{lrrrr}
\hline Characteristics & Control & Teaching & Mentoring & Total \\
\hline Age (years) Mean (s.e.) & $15.3(0.1)$ & $15.3(0.1)$ & $15.2(0.1)$ & $15.3(0.1)$ \\
Education (years) Mean (s.e.) & $7.7(0.1)$ & $8.1(0.1)$ & $7.7(0.1)$ & $7.8(0.1)$ \\
Currently in-school in percent & 93.4 & 95.2 & 95.7 & 94.8 \\
Siblings (number) Mean (s.e.) & $3.6(0.1)$ & $3.4(0.1)$ & $3.7(0.1)$ & $3.6(0.1)$ \\
Mother's education (years) Mean (s.e.) & $2.2(0.2)$ & $2.5(0.2)$ & $2.2(0.2)$ & $2.3(0.1)$ \\
Father's education (years) Mean (s.e.) & $3.8(0.3)$ & $4.0(0.3)$ & $3.7(0.3)$ & $3.8(0.2)$ \\
\hline N & 197 & 188 & 235 & 620 \\
\hline
\end{tabular}




\section{Table A.2.1: List of short-term outcome variables}

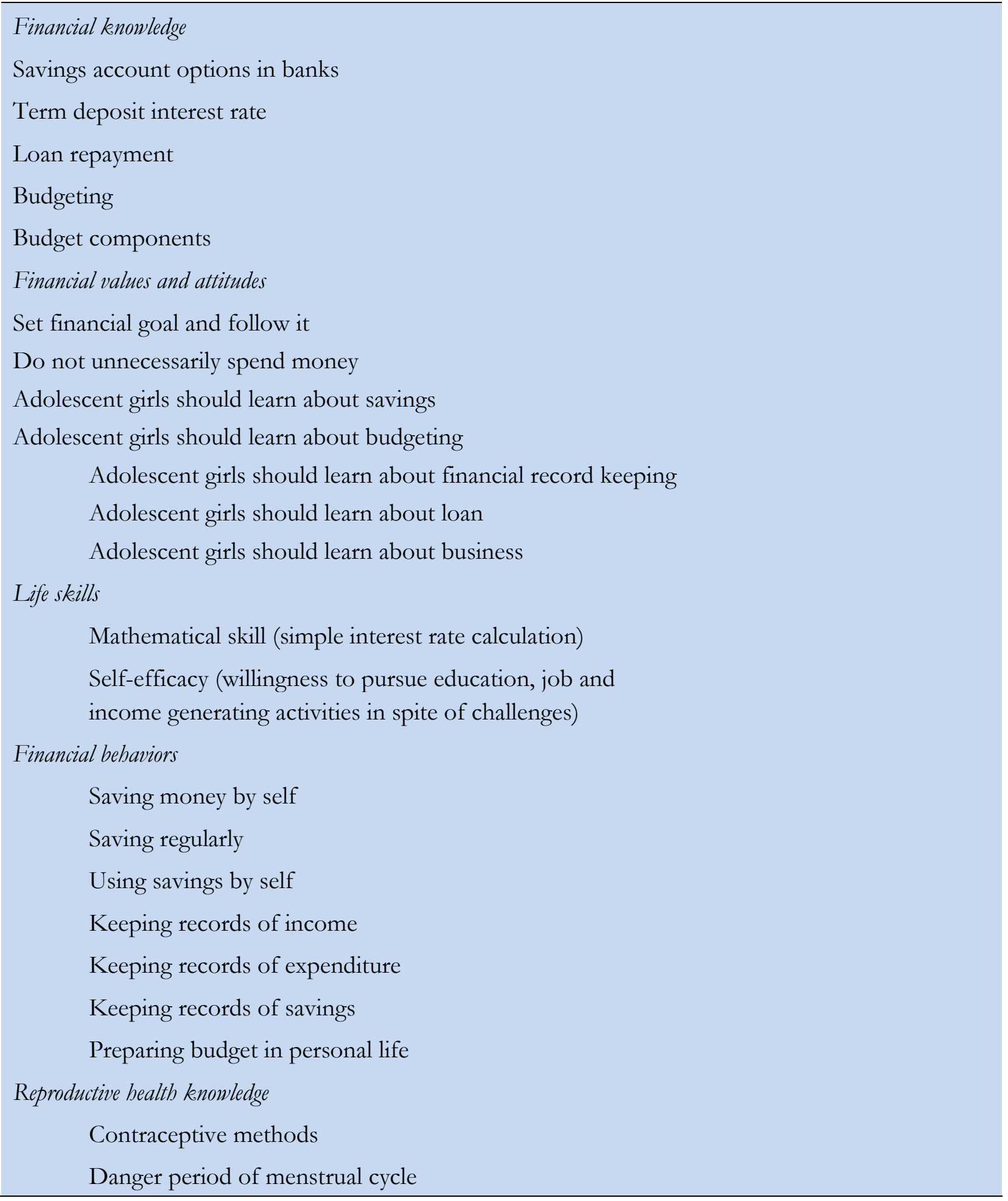


Table A.2.2: List of controlling and explanatory variables

Controlling factors
Community characteristics:
Location (Rural=0; Urban=1)
Household characteristics:
Father's years of education
Mother's occupation (Not housewife=0; Housewife=1)
Individual characteristics:
Marital status (0-married; 1 -unmarried)
Media exposure (0-didn't watch television; 1 -watched television)
Baseline value of outcome variable; e.g., financial knowledge/value/skills/behavior
Explanatory factors
Exposure to F.E. Education: (Control arm: 0; Teaching arm: 1; Mentoring arm: 2)

Qualitative study

Table A.2.3. Qualitative data collection according to sites

\begin{tabular}{lccr}
\hline Type of data & Rural & Urban & Total \\
\hline Focus group discussion with adolescent girls & 4 & 4 & 8 \\
In-depth interview with young women & 11 & 6 & 17 \\
In-depth interview with program managers & 4 & 5 & 9 \\
\end{tabular}




\section{(P) Population Council}

www.popcouncil.org

House CES (B) 21, Road 118

Gulshan, Dhaka 1212

Bangladesh

Phone: 8802 8821227/8826657

Fax: 88028823127 